\title{
Knowledge dynamics at the firm-user community boundary: A Community of Practice view
}

\begin{abstract}
In this paper, we address the need for newer approaches to engage with the interactive nature of knowledge exchange that occurs when firms engage in open innovation with user communities. Drawing on the Community of Practice perspective, we develop a relational framework that forms the basis for examining the social dynamics underpinning knowledge collaboration between the firm and the community. This framework integrates the perspective of community (and its users) with the host firm to enable a comprehensive investigation of the tensions associated with the dynamics at the firm-community boundary, and how these tensions can be managed generatively to enable seamless co-creation of knowledge and innovation. We discuss how researchers can use the framework for future studies that seek to better understand the complex, relational dynamics of firm-community knowledge collaboration. These insights are valuable for firms to support knowledge collaboration by focusing on effective boundary management practices for negotiating tensions that emanate at the firm-community boundary.
\end{abstract}

Keywords: Open innovation; User communities; Communities of practice; Knowledge collaboration 


\section{Knowledge dynamics at the firm-user community boundary: A Community of Practice view}

\section{Introduction}

Organizations increasingly engage in open innovation (OI) by collaborating and exchanging knowledge with communities of users across their boundaries (Chesbrough, 2003; Chesbrough \& Bogers, 2014; West et al., 2014). Often this happens via online, web-based platforms that firms host as a deliberate means of leveraging user communities for the co-creation of knowledge and innovation (Jeppesen \& Frederiksen, 2006; Wiertz \& de Ruyter, 2007). Despite their growing prevalence, firm-hosted user communities (FHUC) have received only little attention in the OI literature (Randhawa et al., 2016; West \& Lakhani, 2008). As a result, we do not know much about how firms can manage knowledge collaboration with FHUCs for OI.

Studies on user innovation (e.g., Füller et al., 2008; von Hippel \& von Krogh, 2003) and community-based innovation (e.g., Nambisan \& Baron, 2009) have directed more attention to user communities as compared to OI research, but their emphasis has been on intra-community aspects and the role of users as innovators, and not on how the firm captures value through the purposive exchange of knowledge with user communities (Lauritzen et al., 2013; Piller \& West, 2014). In OI via FHUCs, users not only interact and share knowledge within the community, but also with the host firm and its members (Hienerth et al., 2014). This highlights the need to focus on the knowledge dynamics that occur at the boundary between the firm and the community - an area that remains under-researched (e.g., Dahlander et al., 2008; Dahlander \& Magnusson, 2005; Hienerth et al., 2011; West \& Lakhani, 2008).

Till date, the majority of OI studies have taken a firm-centric approach, directing attention to the integration and use of external knowledge to boost the firm's internal R\&D and innovation 
outcomes (West \& Bogers, 2014). Accordingly, researchers have primarily drawn on classical knowledge theories namely absorptive capacity (Cohen \& Levinthal, 1990), exploration and exploitation (March, 1991; Rivette \& Kline, 2000) and the knowledge-based view (Kogut \& Zander, 1996), to study knowledge flows across inter-firm dyads, and more recently, in networkbased structures (Piller \& West, 2014; Randhawa et al., 2016; Vanhaverbeke et al., 2014). Knowledge exchange here is governed by formal arrangements such as R\&D contracts, technology partnerships or IP transfer agreements (e.g., Chesbrough, 2006; Vanhaverbeke et al., 2008; West \& Gallagher, 2006), and knowledge itself is conceived as resource stocks in the form of IP or technology (Piller \& West, 2014).

Communities have been recognized as separate extra-organizational sources of knowledge and innovation (West \& Lakhani, 2008; Dahlander \& Frederiksen, 2012). Distinct to inter-firm dyads or network contexts, OI via FHUCs emerges through an interactive coupled model (Piller \& West, 2014; West \& Bogers, 2014). Here knowledge is co-created in the community, a largely autonomous entity that is outside the hierarchical realm of the firm (Lee \& Cole, 2003; O’Mahoney \& Bechky, 2008). Innovation in this context is jointly produced through iterative knowledge exchange between the firm and the user community, and amongst users within the community itself, thus introducing much more complex, social dynamics to knowledge collaboration (Chesbrough \& Bogers, 2014). Adding to this complexity, these entities are driven by competing goals and motives: while the host firm primarily seeks to capture commercial value from community-driven OI, users engage in the community to create and derive social value (Piller \& West, 2014). As a result, tensions emerge at the boundary between the firm and community, which the host firm must tackle to maintain seamless firm-community knowledge collaboration (Faraj et al., 2011; Lauritzen et al., 2013). 
In this paper, we argue that these complex dynamics within and across FHUCs challenge the traditional firm-centric approaches to studying knowledge exchange in OI, and warrant a more relational perspective to address the interactive coupled form of knowledge collaboration that occurs across the firm-community boundary. Rethinking firm-based views on knowledge management, Lee and Cole (2003) proposed a new community-based model of knowledge creation in the context of Open Source Software communities. Other scholars have raised the need for adopting a processual perspective to engage with the tensions underpinning communitybased knowledge collaboration (e.g., Faraj et al., 2011), and have suggested the applicability of Community of Practice (CoP) (Brown \& Duguid, 1991; Wenger, 1998; Lave \& Wenger, 1991) as a lens to study the role of communities in OI (e.g., West \& Lakhani, 2008; O’Mahony \& Lakhani, 2011). Our goal in this paper is to respond to these calls, and extend such work by drawing on a CoP perspective to develop a process-based framework to examine and manage knowledge dynamics at the firm-community boundary. Different to traditional knowledge theories, the CoP lens provides a relational perspective on knowledge that accounts for the social complexity of firm-community knowledge exchange, viewing it as a process that goes beyond the formally governed transfer of knowledge stocks (Swan, 2007; Lee \& Cole, 2003).

Our CoP-based relational framework integrates the perspective of the community (and its users) with the host firm, thus extending the hitherto firm-centric view to studying knowledge exchange in OI, and focuses on the social dynamics between these entities as the seat of knowledge collaboration through which OI emerges from FHUCs. The framework forms the basis to examine how tensions emanate and interact across the firm-community boundary, and how firms can generatively manage them to enable the co-creation of knowledge and innovation. We suggest how future empirical research can apply our framework to study knowledge dynamics at 
interface between firms and communities. Our paper thus makes a contribution toward advancing an understanding of how firms can manage knowledge collaboration at the firmcommunity boundary and capture value from community-based OI.

\section{Literature review and theoretical background}

\section{OI in inter-firm dyads and networks: the role of traditional theories to study knowledge collaboration}

The OI literature identifies three modes of knowledge exchange between the firm and its innovation partners: (1) inbound (or outside-in), which involves the access and integration of knowledge from external sources to accelerate a firm's internal innovation process; (2) outbound (or inside-out), which involves the outflow and commercialization of a firm's internally developed knowledge to bring ideas to market; and (3) coupled, which combines outside-in process with the inside-out process between complementary partners such as those in inter-firm alliances (Enkel et al., 2009; Gassmann \& Enkel, 2004) (Chesbrough, 2003; West \& Gallagher, 2006). Thus, inbound and outbound modes of OI involve a unidirectional flow of knowledge into or out of a firm respectively, while the coupled process is based on inter-firm dyadic collaboration and bidirectional knowledge flows (West \& Bogers, 2014). Research, albeit relatively lesser, has also focused on how firms utilize inter-firm networks as external source of knowledge and innovation (Vanhaverbeke \& Cloodt, 2006). Knowledge exchange in these arrangements are generally governed by formal arrangements such as alliances or monetized through licenses (Aslesen \& Freel, 2012; Lichtenthaler \& Lichtenthaler, 2009).

With respect to theoretical perspectives adopted, a significant body of OI research draws on absorptive capacity (Cohen \& Levinthal, 1990) to investigate how firms can absorb and utilize external knowledge for OI (e.g., Cassiman \& Veugelers, 2006), and the linkage between 
absorptive capacity and innovation performance (e.g., Rothaermel \& Alexandre, 2009; Fabrizio, 2009). The knowledge-based view of the firm (Grant, 1996; Kogut \& Zander, 1992) and knowledge creation theory (Nonaka \& Takeuchi, 1995) is used to study the role of capabilities in accessing, converting and assimilating externally developed knowledge (Vanhaverbeke et al., 2008) in boosting OI outcomes (e.g., Huggins, 2010; Ordanini \& Maglio, 2009). OI studies also draw on March's (1991) notion of exploration and exploitation to investigate how firms can explore external knowledge (for instance, to source IP and technology through in-licensing) (e.g.,Arora et al., 2001) and exploit knowledge (for instance, to commercialize IP and technology through out-licensing) (e.g., Chesbrough, 2006; Vanhaverbeke et al., 2008; West \& Gallagher, 2006).

In sum, it is evident that OI research till date has predominantly adopted a firm-centric perspective to investigate mechanisms of knowledge exchange using classical knowledge theories (i.e. absorptive capacity, knowledge-based view and knowledge exploration and exploitation) (West \& Bogers, 2014) (Randhawa et al., 2016). These knowledge theories are underpinned by the assumption that knowledge is a discrete resource that can be developed and exchanged between entities through formal processes of knowledge creation and transfer (Swan, 2007). Knowledge can be objectified, and hence converted from one form to another (eg., tacit to explicit) (Nonaka \& Takeuchi, 1995). This view of "knowledge as possession" (Cook \& Brown, 1999) has suited extant research where the focus has been on transfer of technology or IP as knowledge resources into a firm's internal innovation process, across inter-firm dyads or network-based structures formalized through R\&D alliances, technology partnerships or IP transfer agreements. 


\section{OI via user communities: the need for new approaches to study knowledge collaboration}

Today OI occurs increasingly when firms tap into communities of users as external sources of knowledge and innovation (Baldwin \& von Hippel, 2011; Piller \& West, 2014). These communities differ from OI networks in being emergent, voluntary associations of users characterized by autonomy, mutuality and shared identities (West \& Bogers, 2014; Dahlander \& Frederiksen, 2012). Firms host communities on online platforms to exchange knowledge with users along the OI process including co-ideation (e.g., Starbuck's 'MyStarbucksIdea' and Dell's 'IdeaStorm'), co-design (e.g., Lego's 'Mindstorm' and Nike's 'Niketalk') and co-testing (e.g., Xerox's 'Open Xerox' and Nokia's 'Betalabsnokia'), and sometimes base their entire business model on such community-based OI (e.g., Threadless). Although FHUCs are burgeoning in practice, they have received only limited attention in the OI literature (Randhawa et al., 2016; West \& Lakhani, 2008).

User innovation (e.g., Füller et al., 2008; von Hippel \& von Krogh, 2003) and community-based innovation studies (e.g., Nambisan \& Baron, 2009) have focused more on user communities, but these streams, driven by their orientation towards the users' social value creation, have almost exclusively examined intra-community aspects, such as peer-to-peer assistance in Open Source Software (OSS) (Lakhani \& Von Hippel, 2003) and sporting goods (e.g., Franke \& Shah, 2003; Shah, 2006). FHUCs, where users contribute to innovations that are commercialized by firms, can be considered as a source of OI that involves knowledge exchange between the host firm and the user community (Piller \& West., 2014). Therefore, we need a better understanding of knowledge flows at the firm-community boundary as the key enabler of firms' value capture through community-based OI (e.g., Dahlander et al., 2008; Dahlander \& Magnusson, 2005; West \& Lakhani, 2008). 
There are two main characteristics of knowledge collaboration in community-based OI which differentiate it from other inter-firm modes of knowledge exchange discussed earlier. First, OI via FHUCs can be viewed as occurring through an interactive coupled mode (Piller \& West, 2014; West \& Bogers, 2014), where knowledge is co-created external to the focal firm in the community through collaborative practices between the host firm and the community. Furthermore, as FHUCs are self-governing structures falling outside the firm's hierarchy, knowledge collaboration in this type of OI cannot be isolated from the autonomous many-tomany social interactions that users engage in within the community (Lee \& Cole, 2003). This is different to the coupled mode of OI in inter-firm dyads and networks where knowledge is produced independently by each firm and then transferred to the other, and this exchange is controlled and governed by formal contracts.

Second, knowledge exchange across the firm-community boundary is affected by competing goals and demands of the firm and the community members: while the host firm members are driven by the firm's strategic intent for value capture and profit appropriability, users are primarily motivated by their regard for social value creation through communal exchange and collective action (e.g, Shah, 2006), mutual cooperation and reciprocity (e.g., Lakhani \& Von Hippel, 2003), or other intrinsic motives for participation such as enjoyment or task achievement (e.g., von Hippel \& von Krogh, 2003). In the absence of formal contracts governing knowledge exchange across FHUCs, these contrasting motives signify sources of tensions when firms and communities interact (Piller \& West, 2014; Lauritzen et al., 2013), and hence has a bearing on the knowledge dynamics at the firm-community interface.

Therefore, a theoretical framework to understand firm-community knowledge dynamics needs to account for: (1) the many-to-many interactive knowledge sharing processes within the 
community and the one-to-many knowledge exchange processes between the firm and the community, as well as (2) the tensions unfolding at the boundary between the firm and the community, and how they affect knowledge collaboration. Conventional knowledge theories hitherto used by OI researchers in the context of inter-firm dyads or networks, that view knowledge as an acquirable resource and knowledge transfer as a formal, mechanistic process, appear inadequate to address the complex, relational processes underpinning knowledge exchange in OI via FHUCs. We suggest that the CoP perspective that conceives knowledge as situated in social processes (Brown \& Duguid, 1991; Wenger, 1998) is better equipped to address the dynamics of firm-community knowledge collaboration.

Previous research has raised the need for adopting a process perspective to examine the relationships between communities and firms (O’Mahony \& Lakhani, 2011), and to engage with the tensions associated with the dynamics of knowledge collaboration in online communities (Faraj et al., 2011). Scholars have also indicated the applicability of CoP as a lens to study the role of communities in OI (West \& Lakhani, 2008; O’Mahony \& Lakhani, 2011). Acknowledging the inability of firm-based views of knowledge to explain distributed knowledge creation, Lee and Cole (2003) have developed a new community-based model in the context of Open Source Software communities. Responding to these calls and extending such work, in this paper, we adopt a $\mathrm{CoP}$ perspective to understand and explain the knowledge dynamics when OI occurs via FHUCs.

In the next section, after elucidating why CoP view on knowledge is well-suited to our research context, we develop a conceptualization of firm-community knowledge collaboration based on a CoP perspective. Following this, we build a relational framework that integrates organizational with extra-organizational perspectives (Vanhaverbeke et al., 2014; West \& Lakhani, 2008; West 
et al., 2014), and connects the pivotal entities - host firm and community (and its users) - with a particular focus on the social dynamics that underpin knowledge collaboration across the firmcommunity boundary. Our framework forms the basis to engage with the tensions at the firmcommunity boundary, and how firms can manage them to maintain seamless knowledge collaboration. We then suggest an agenda for future researchers to study various facets of the firm-community knowledge dynamics.

\section{Firm-community knowledge collaboration: A 'Community of Practice' perspective}

\section{Why a 'Community of Practice' view on knowledge for OI via FHUCs?}

Three tenets of the CoP view of knowledge as identified by Carlile (2002), differentiate it from traditional knowledge theories, and make it more suitable as a framework for studying the knowledge dynamics underpinning OI via FHUCs. First, the CoP perspective views knowledge as embedded in practice, that is, it is constituted in social relations, and is co-produced through social interactions in a community context (Brown \& Duguid, 1991; Wenger, 1998; Lave \& Wenger, 1991). Knowledge is therefore seen as something people 'do' mutually in a collective setting as opposed to something that firms possess, acquire and transfer in the form of IP or technology (Swan, 2007). Thus, the CoP perspective acknowledges the socially situated, interactive nature of knowledge as something beyond a well-defined, easily codifiable substance (Brown \& Duguid, 1996; Lave, 1988).

Second, knowledge is seen as localized in practice, and innovation as emerging from the improvisational ways in which members solve specialized problems within the community (Lave and Wenger, 1991; Brown \& Duguid, 2001). Third, knowledge is said to be invested in practice as members tend to protect knowledge that they have developed locally; hence this knowledge is 
'at stake' for those who have invested in it. These characteristics, while useful for the creation of knowledge within a $\mathrm{CoP}$, pose a challenge for exchange of knowledge across a CoP, as they give rise to 'knowledge boundaries' (Carlile, 2002, 2004), which can hinder the capture of innovation by the firm initiating the CoP (Brown \& Duguid, 2001; Swan et al., 2007). Tensions arise at these boundaries due to conflicting identities and worldviews, as well as goals and motivations between the interacting entities (Handley et al., 2006; Hong \& Fiona, 2009).

In sum, by providing a processual perspective on knowledge, the $\mathrm{CoP}$ lens specifically sensitizes us to the importance of relational exchanges in shaping knowledge collaboration. Knowledge here is not a resource that resides in cognitive or technological structures, but is instead an activity that people 'do' together in a social context (Nicolini, 2011). In this way, the CoP view accounts for the social complexity of knowledge exchange underpinning OI via FHUCs, viewing it as a process that is beyond mere acquisition and transfer of knowledge stocks (Thompson, 2005). This perspective also highlights the "stickiness" of knowledge recognizing how 'knowledge boundaries' are created at the interface between firms and communities (Carlile, 2002, 2004), and how tensions at these boundaries have to be negotiated for effective firmcommunity knowledge collaboration (Duguid, 2005). Hence, we posit that the CoP lens is pertinent to our context of OI via FHUCs.

\section{A 'Community of Practice’ conceptualization of knowledge collaboration}

The idea of knowledge in CoP is underpinned by how it has been conceived in wider practicebased studies; that is, knowledge is seen as situated in practices, leading to the notions of knowing-in-practice (Gherardi, 2008; Gherardi \& Nicolini, 2000). Put differently, "knowing is an ongoing social accomplishment, constituted and reconstituted in everyday practice" (Orlikowski, 2002, p. 252). These works draw on earlier ideas on human knowledgeability that 
view knowledge as actively constructed in social practice (Bourdieu, 1977), intricately tied to social routines (Giddens, 1979) and situated action (Lave, 1988).

A CoP perspective adopts a wider meaning of the term 'practice'. Practice is not just wellcodified routines; it is action informed by meaning drawn from the community context (Cook and Brown, 1989). Practice thus entails meaningful engagement by members in the community (Handley et al., 2006). Meaning here is developed when members develop an understanding of who they are and how they belong to the community through their participation in the community's shared practice (Wenger, 1998; 2000). This implies that the issue of the development of social identity by members is an important concern to engaging in social practice. In this way, CoPs engender individual member identities that are tied to collective practices of the community (Swan et al., 2002). Therefore, member identities are also critical to how knowledge collaboration occurs in a CoP.

Viewed through a CoP lens, knowledge developed in FHUC is thus embedded in the collective practices of the community and involves the construction of individual user identities through their participation in the community. Therefore, the two concepts we see as intricately linked to knowledge collaboration in a FHUC are practice and identity. The relationship between knowledge, practice and identity spurs a "virtuous circle": the more users engage in the practice, the more they inter-subjectively produce and exchange knowledge, and the more they identify with the community, which in turn motivates them to participate more in the community's practice (Thompson, 2005). Thus, the CoP perspective acknowledges the complex, social dynamics of knowledge collaboration at the collective community as well as the individual user levels within a FHUC. By integrating individual users and the collective community with knowledge collaboration within and across communities, the $\mathrm{CoP}$ approach provides a way to 
extend the firm-centric approach to studying knowledge exchange prevalent in extant OI research.

In line with the initial conceptualizations of CoPs as "cohesive and homogenous social objects" (Handley et al., 2006; p. 642), early studies focused on the ease with which members share knowledge through mutuality, joint practices and shared identities (Hong \& Fiona, 2009; Roberts, 2006). Recent work has however emphasized the potential for tensions across CoPs caused by embedded power differentials (Hong \& Fiona, 2009; Roberts, 2006; Swan et al., 2002; Thompson, 2005) and multiple identities (Handley et al., 2006; Hong et al., 2009). These tensions are the core of knowledge dynamics at the firm-community boundary. This brings into question how the $\mathrm{CoP}$ perspective can inform us about the role of boundaries in knowledge exchange across FHUCs.

Boundaries are said to play a paradoxical role in CoPs. While boundaries can create divisions and pose difficulties in knowledge exchange, they can also be the link between the CoP and the external entity, and hence a space which offers new opportunities for knowledge collaboration and innovation (Wenger, 2000; Swan et al., 2002; Duguid, 2005). Applying Carlile (2002, 2004), knowledge collaboration across FHUCs requires traversing 'knowledge boundaries' formed due to competing practices and identity structures between the host firm and community (Handley et al., 2006; Hong \& Fiona, 2009). We return to the topic of firm-community 'knowledge boundaries', and how they can be managed later in the paper.

\section{Relational framework of firm-community knowledge collaboration}

Employing a CoP perspective, we have conceived knowledge collaboration as emerging out of users' engaging in the social practices of the FHUC and constructing social identity through this process of participation. This conceptualization reflects the two constitutive and inter-related 
concepts that lie at the core of the dynamics of firm-community knowledge collaboration: practice (at the collective community level) and identity (at the individual user level). In this section, we further develop the dynamics underlying these concepts. We argue that dynamics of power relations emerge through competing practices between the firm and the community. Dynamics of social identity construction emanates when users construct multiple identities in relation to the firm and community. The development of practice and identity through participation in FHUC, and their associated knowledge dynamics at the firm-community boundary forms the basis of our relational framework (Figure 1).

Insert Figure 1 here

\section{Practice: Dynamics of power relations}

From a CoP viewpoint, knowledge is situated in social practice, and is inseparable from it. Here, practice refers to engaging in a task in a meaningful way within a collective context (Brown \& Duguid, 1991). Accordingly, FHUC can be seen as constituted of and produced by social practices that the actors - (user) community and host firm members - collaboratively engage in (Nicolini, 2011; Schatzki, 1996, 2005). Knowledge collaboration is thus integrally tied to social practices within and across the FHUC.

Practices can be of two types: canonical and non-canonical (Brown \& Duguid, 2001; Duguid, 2005). Canonical practices take the form of explicit rules and convey 'know-that' to users. These include procedures, tasks and norms for participation laid down by the host firm to govern the user community's actions. 'Know-how' is however developed via non-canonical practices that users form by adopting tacit cultural templates of the community including community norms, values, rituals and conventions. These shape users' practical understandings of what to say and do in the collective context (Schatzki, 2005). 
The firm's canonical practices and the user community's non-canonical practices connect and interact. In doing so, they give rise to tensions related to power dynamics at the interface between firms and communities (Osterlund \& Carlile, 2005; Roberts, 2006). The fact that FHUCs are not fully autonomous CoPs, and that firms control and direct the community through the use of rules, policies and other canonical practices, implies that power relations are implicit in the social practice. Yet, the community also develops self-governing, non-canonical norms, values and rituals that guide how users engage in the community. Thus, FHUCs manifest asymmetrical power relations as tension between explicit, canonical governance practices of the host firm and the tacit, non-canonical self-governance practices of the community. Tensions related to these power differentials can distract the collective knowledge collaboration process at the firm-community boundary. A better understanding of how these actually plays out in FHUCs can feed into better alignment of governance practices by the host firm - a topic of pertinence to OI research (Dahlander et al., 2008).

\section{Identity: Dynamics of social identity construction}

In a $\mathrm{CoP}$, users construct social identities through their participation in the community's practice. (Wenger, 1998; Handley et al., 2006). Therefore, knowing in a CoP is also tied to how users develop a sense of belonging to the community resulting in the formation, interpretation and negotiation of the individual users' position in the community (who they are) and the ways they are related to each other (what they do) (Albert \& Whetten, 1985). This reveals the social, dynamic nature of identity formation.

In FHUCs, user identities reflect two types of social relations. The first type is linked to community membership how users identify with the community. The second type is bound to their perceptive association with the firm and relates to how they identify with the host firm. 
Users derive social value by assigning meaning to their engagement with both the firm and the community, which results in the formation of dual or sometimes multiple social identities among users.

Adapting the work of Alvesson \& Willmott (2002), Handley et al., (2006) link the individual identity in a CoP to two processes of identity construction: (1) identity-regulation and (2) identity-work. Applying this to FHUC, identity regulation refers to the efforts of the host firm in regulating or mediating user identification with the community and the firm. Identity-work refers to the user's own continuous efforts to form, maintain or revise their perceptions of self. These processes of social identity construction are in constant interplay in FHUCs. The dynamics of identity in FHUCs can be viewed as an interaction between the processes of identity-regulation by the host firm and identity-work by the user participants. The users' identity-work involves a negotiation between the firm's efforts at identity-regulation (which the user may or may not adhere to) and the sense of self derived from the user's own current identity work. These dynamics harbor tensions due to the co-construction of multiple identities by users based on their differential identification with the community versus the host firm. Focusing on these can help firms align community engagement in such a way that their identity-regulation practice aids the users' practices of social, symbolic value creation through their social identity-work.

In developing our relational framework on firm-community knowledge collaboration, we have so far discussed how the co-evolution of practice and identity in FHUCs create tensions associated with power relations and social identity construction at the firm-community boundary. In order to maintain seamless knowledge collaboration, these tensions emanating at the firm-community boundary will need to be negotiated (Handley et al., 2006; Brown and Duguid, 2001). In this 
light, we now address the role of 'knowledge boundaries', and how they can be generatively managed by firms.

\section{Managing knowledge dynamics at the firm-community boundary}

Carlile (2002, 2004) identify three kinds of 'knowledge boundaries' shaped by practice: synctatic, semantic and pragmatic, which present different degrees of complexity for OI via FHUCs. Synctatic boundaries can be crossed through the use of a common syntax to match diverging informational aspects between the firm and its partner. The requirement here is that of simplistic knowledge transfer across the boundary (Carlile, 2002). This boundary is what is encountered in conventional inter-firm dyads and network-based mechanisms of OI such as R\&D alliances and technology partnerships where specific contracting arrangements between the parties enable the firms to establish common practices for structuring and transferring information, and thus contract efficiently (Sapsed \& Salter, 2004).

A semantic boundary is more complex. Here, the concern for knowledge exchange is that of perspective-taking' whereby the CoP recognizes, accommodates and reconciles differences in interpretations with the external entity (Boland \& Tenkasi, 1995, p. 359). In such circumstances, a common syntax is no longer sufficient as there is a need to develop common meanings in order to translate knowledge. This is true for FHUCs, as the user community and firm members are expected to interpret each others' meanings and identities in order to pursue innovation. Traversing sematic boundaries is hence required to manage the relatively more complex tensions of multiple social identities at the firm-community interface.

Pragmatic boundaries are the most complex, as they are associated with differences in motivations and political interests between those involved. This kind of boundary is particularly prevalent in FHUCs, which is fraught with tensions related to power differentials caused due to 
competing goals and practices between firms and user communities. Common meanings established by crossing semantic boundaries are no longer adequate as actors may still not reconcile practices as a result of conflicting motivations. In order to transform knowledge, firms need to negotiate tensions related to asymmetrical power by crossing pragmatic boundaries (Carlile, 2004).

The CoP literature has focused on how organizations can "cultivate" CoPs (Wenger \& Snyder, 2000) so as to manage the process of innovation (Swan et al., 2002). The role of the host firm in cultivating FHUCs is to manage the tensions at the firm-community boundary so as to maintain seamless knowledge collaboration by crossing the corresponding synctatic (language), semantic (identity) and pragmatic (power) boundaries. Crossing synctatic boundaries aids information or knowledge transfer. Traversing sematic boundaries addresses the dynamics of social identity construction, and is required for knowledge translation. Further, in order to negotiate the power dynamics, firms need to cross pragmatic boundaries. Doing so enables transformation of knowledge between the firm and the community. This however is not an easy task as it requires nuanced and ongoing boundary management processes to provide constructive support to the community without constraining the delicate dynamics by which they are sustained (Thompson, 2005; Brown \& Duguid, 2001).

Practice scholars have pointed to the role of boundary objects (Carlile, 2002, 2004; Swan et al., 2007) and boundary spanners (Wenger, 2000) in aiding this process. Boundary spanners are brokers who connect CoPs by introducing elements of one practice into another (Wenger, 2000). In FHUCs, host firm members can be seen as boundary spanners whose role it is to manage tensions at the firm-community boundary by being a 'systems builder' (Swan et al., 2002), structuring spontaneity (Brown \& Duguid, 2001) and brokering relationships (Wenger, 2000) in 
such a way that the dynamics between host firm and user community cohere in a mutually sustaining way (Schatzki, 2005).

Boundary objects are defined as “....artifacts, documents, terms, concepts, and other forms of reification around which communities of practice can organize their interactions" (Wenger, 1998, p. 105). They can play a key role in shaping practice and identity in CoPs as they provide focal points around which people can interact and identity with (Thompson, 2005), and thus enable knowledge sharing from one domain to another (Bechky, 2003; Carlile, 2002; Star \& Griesemer, 1989). In FHUCs, host firms employ a range of boundary objects in the form of online collaboration platform and tools that can aid firm-community knowledge collaboration.

By deploying firm members as boundary spanners and online collaborative platform and tools as boundary objects, host firms can achieve a high level of influence and engagement with the community (Swan et al., 2002). To be effective, these boundary spanners and objects should be specifically oriented toward managing the dynamics of asymmetrical power relations and multiple identities. In terms of negotiating power dynamics, boundary spanners and objects should focus on the balance between control and openness in communities, so as to preserve noncanonical, self-governance practices of the community, while simultaneously aligning and coordinating their activities through canonical practices.

In relation to managing identity dynamics, the challenge for boundary spanners and boundary objects is to aid social identity construction by building connectedness - through enduring social relationships; expansiveness - by finding a way to allow multiple identities to co-exist in harmony; effectiveness - by using identity as a vehicle for sustained participation (Wenger, 2000). Finally, boundary spanners and boundary objects themselves can convey symbolic messages or 'social value' which can have more impact than their instrumental characteristics 
(Swan et al., 2007; Levina and Vaast, 2005). In OI via FHUCs, it may be these intangible and symbolic aspects that are more crucial to creating a shared context for the translation and transformation of knowledge (Carlile, 2002, 2004).

\section{Discussion and future research avenues}

In this paper, we argue that there is a need for newer approaches to address the interactive coupled form of knowledge exchange that occurs when firms engage in OI with user communities. Following scholars who have suggested that applicability of CoP as a lens to study the role of communities in OI (e.g., Lee \& Cole, 2003; O’Mahony \& Lakhani, 2011; West \& Lakhani, 2008), we employ a CoP perspective to frame knowledge collaboration at firmcommunity boundary. Different to traditional firm-centric views of knowledge creation, the CoP lens provides a relational perspective on knowledge that accounts for complex nature of knowledge exchange within and across FHUCs (Swan, 2007; Lee \& Cole, 2003). Our relational framework is useful to engage with: (1) a fine-grained analysis of the social dynamics underpinning firm-community knowledge collaboration, (2) how tensions related to the dynamics of power differentials and multiple identities emerge and interact at the firmcommunity boundary, and (3) how these tensions can be managed generatively to negotiate knowledge boundaries.

CoP offers a lens for examining the dynamics of knowledge collaboration at the firm-community boundary through an understanding of the dynamics of shared practice (at the collective community level) and identity formation (at the individual member level), and their interplay with the host firm's practices. The co-evolution of practice and identity in FHUCs create tensions associated with power relations and social identity construction at the firm-community boundary. Our CoP-based conceptualization suggests that tensions are constitutive of the 
dynamics that underpin cross-boundary knowledge exchange. Therefore, focusing on these tensions provides a useful way to empirically engage with the complex, social dynamics of knowledge exchange at the firm-community boundary.

Viewed through a CoP lens, these tensions can never be fully resolved but can be generatively managed at the firm-community boundary. Similar to Siedlok et al. (2015), we posit that understanding the tensions that underpin firm-community knowledge dynamics can help host firms formulate support initiatives that aid in orchestrating the firm's practices with those of the (user) community, and thus overcome barriers to the creation and capture of value through community-based OI. We offer insights into the processes involved in supporting knowledge collaboration by focusing on the role of boundary spanners and boundary objects in traversing knowledge boundaries in the firm-community context. Doing so can aid a better balance between how firms govern communities and how communities derive social, symbolic value, to eventually translate into better firm-community knowledge collaboration.

Our conceptualization of firm-community knowledge collaboration implies that the host firm's practices cannot be investigated exclusively from a firm's perspective but only through an understanding of their interplay with how the (user) community engages with these practices. We suggest how our framework can form the basis for future research that seeks to engage with the dynamics of firm-community knowledge collaboration. Table 1 summarises four key aspects that can be examined fruitfully using the concepts (and related dynamics) integral to our framework: community governance; social, symbolic value creation; collaboration platform and tools as boundary objects; and host firm members as boundary spanners. 
While the questions related to community governance (power relations) are based at the collective (community) level, those related to social, symbolic value creation (social identity construction) focus on the individual (user) level. Finally, questions related to the role of boundary spanners (host firm members) and boundary objects (collaborative platform and tools) operate from the host firm's perspective. Thus, our relational framework incorporates the user and community perspectives, to enable an examination of firm-community knowledge collaboration both at the collective and individual level, thus extending the existing firm-level approach prevalent in extant OI research (West \& Bogers, 2014; Randhawa et al., 2016).

In keeping with the social practice perspective inherent in our framework, the focus goes beyond studying structural aspects of FHUCs, to the actual enactment of practices by actors, as the key to knowledge collaboration (Brown \& Duguid, 1991; Gherardi, 2009; Roberts, 2006). Thus, we respond to the calls of OI researchers for a processual perspective to engage with the tensions underpinning community-based knowledge collaboration (e.g., Faraj et al., 2011) and to study the role of communities in OI (e.g., O'Mahony \& Lakhani, 2011). This is also in sync with the view of practice scholars who note the merit in reversing the terminology from CoP to the 'practice of community' (Gherardi, 2009) to indicate the shift towards the actual practices of people participating in communities. The objective of analysis in such a practice-based study is to focus on the relations between the host firm and the (user) community that unfold in practice (Amin \& Roberts, 2008). The insights gained are useful to advance our understanding of how firms can manage knowledge dynamics at the firm-community boundary. 


\section{Conclusion}

In this paper, we posit that, in the context of FHUCs where OI emerges from an interactive coupled process, knowledge exchange is embedded in the social interactions both within and across the user community. Moreover, the firm-community boundary is fluid producing tensions when firm and communities interact. Conventional knowledge theories hitherto adopted in OI research, while useful to study knowledge flows in inter-firm dyads or networks, do not fully account for such complexity in firm-community knowledge exchange. Responding to this need for newer approaches in studying the interactive, collaborative nature of knowledge exchange between the firm and the community engaged in OI, we conceive a way of exploring this phenomenon from a CoP perspective. We offer a relational framework that integrates the perspective of the community (and its users) with the host firm to enable a better understanding of the knowledge dynamics that emanate at the boundary between the firm and the community. This framework forms the basis for examining the firm-community knowledge collaboration through an understanding of the dynamics of shared practice (at the collective community level) and identity formation (at the individual member level), and their interplay with the host firm's practices. We unpack how these dynamics lead to tensions associated with power differentials and multiple identities at the firm-community boundary, and how these tensions can be managed generatively to enable the co-creation of knowledge and innovation. We suggest how future empirical research can apply our framework to study various facets that constitute the dynamics of firm-community knowledge collaboration. These insights are valuable for firms to engage better boundary management practices so as to capture value from community-based OI. 
Figure 1 - Relational framework of firm-community knowledge collaboration

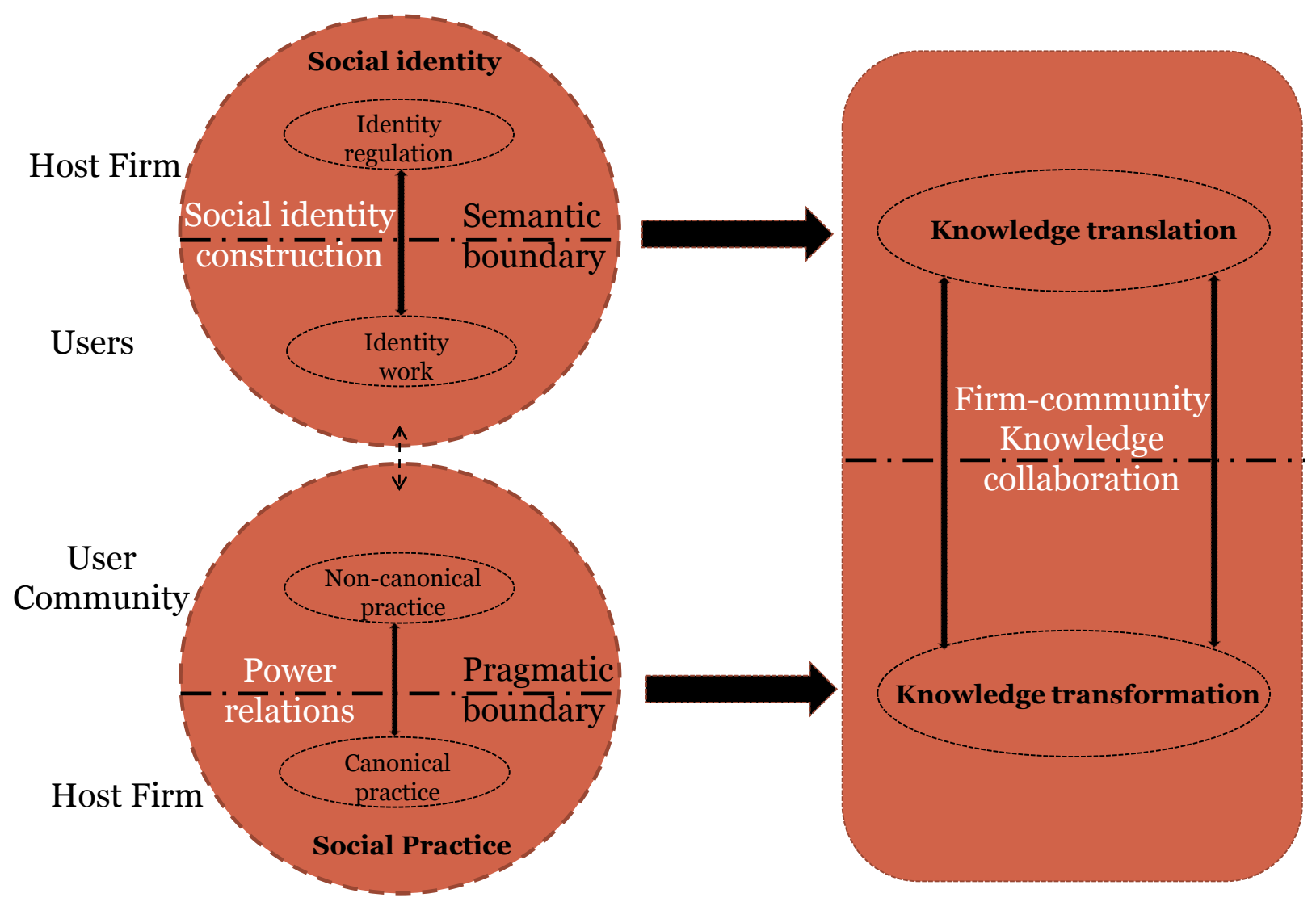


Table 1 - Avenues for future research

\begin{tabular}{|c|c|c|c|c|c|}
\hline Focal perspective & Level of analysis & Aspect of examination & $\begin{array}{c}\text { Related firm-community } \\
\text { dynamic }\end{array}$ & $\begin{array}{c}\text { Related knowedge boundary } \\
\text { (knowledge outcome) }\end{array}$ & Potential research questions \\
\hline Individual & User & Social, symbolic value & Social identity construction & $\begin{array}{l}\text { Semantic boundary } \\
\text { (Knowledge translation) }\end{array}$ & $\begin{array}{l}\text { How do users respond to firm's attempts to regulate or mediate their } \\
\text { identity formation process in the community? } \\
\text { How do users develop co-construct multiple social identities based on } \\
\text { their differential identification with the community and the firm? } \\
\text { How do users derive social, symbolic value by assigning meaning to } \\
\text { their engagement with the firm and the community? }\end{array}$ \\
\hline Collective & User community & Community governance & Power relations & $\begin{array}{c}\text { Pragmatic boundary } \\
\text { (Knowledge transformation) }\end{array}$ & $\begin{array}{l}\text { In what ways do competing goals and motivations between host firm } \\
\text { and community manifest? } \\
\text { To what extent do firm-hosted communities display self-governing } \\
\text { How do the community's self-governance practices interact with the } \\
\text { rules of engagement laid down by the host firm? }\end{array}$ \\
\hline Collective & Host firm & $\begin{array}{l}\text { Role of boundary objects } \\
\text { (Collaborative platform \& tools) } \\
\text { Role of boundary spanners } \\
\text { (Firm members) }\end{array}$ & $\begin{array}{c}\text { Social identity construction } \\
\text { Power relations }\end{array}$ & $\begin{array}{l}\text { Semantic boundary } \\
\text { Pragmatic boundary } \\
\text { (Knowledge translation \& } \\
\text { transformation) }\end{array}$ & $\begin{array}{l}\text { What kind of symbolic messages can collaborative platform and tools } \\
\text { convey so as to shape user identities? } \\
\text { In what ways can firm members enable multiple user identities to co- } \\
\text { exist in harmony? } \\
\text { How can firm members balance control and openness in the way they } \\
\text { deal with communities? } \\
\text { How can collaborative platforms and tools be used to encourage } \\
\text { encourage autonomy and self-governance in communities? }\end{array}$ \\
\hline
\end{tabular}




\section{References}

Albert, S. and Whetten, D.A. 1985. Organizational Identity. Research in organizational behavior.

Alvesson, M. and Willmott, H. 2002. Identity Regulation as Organizational Control: Producing the Appropriate Individual. Journal of management studies 39 619-644.

Amin, A. and Roberts, J. 2008. Knowing in Action: Beyond Communities of Practice. Research policy 37 (2): 353-369.

Ardichvili, A., Page, V. and Wentling, T. 2003. Motivation and Barriers to Participation in Virtual Knowledge-Sharing Communities of Practice. Journal of knowledge management 7 (1): 64-77.

Arora, A., Fosfuri, A. and Gambardella, A. 2001. Specialized Technology Suppliers, International Spillovers and Investment: Evidence from the Chemical Industry. Journal of Development Economics 65 (1): 31-54.

Aslesen, H.W. and Freel, M. 2012. Industrial Knowledge Bases as Drivers of Open Innovation? Industry and Innovation 19 (7): 563-584.

Baldwin, C. and von Hippel, E. 2011. Modeling a Paradigm Shift: From Producer Innovation to User and Open Collaborative Innovation. Organization Science 22 (6): 1399-1417.

Barab, S., Schatz, S. and Scheckler, R. 2004. Using Activity Theory to Conceptualize Online Community and Using Online Community to Conceptualize Activity Theory. Mind, Culture, and Activity 11 (1): 25-47.

Bechky, B.A. 2003. Sharing Meaning across Occupational Communities: The Transformation of Understanding on a Production Floor. Organization science 14 (3): 312-330.

Bogers, M., Afuah, A. and Bastian, B. 2010. Users as Innovators: A Review, Critique, and Future Research Directions. Journal of management.

Bourdieu, P. 1977. Outline of a Theory of Practice. vol. 16. Cambridge university press.

Brown, J.S. and Duguid, P. 1991. Organizational Learning and Communities-of-Practice: Toward a Unified View of Working, Learning, and Innovation. Organization science 2 (1): 40-57.

Brown, J.S. and Duguid, P. 1996. Organizational Learning and Communities of Practice. Organizational learning 58-82.

Brown, J.S. and Duguid, P. 2001. Knowledge and Organization: A Social-Practice Perspective. Organization science 12 (2): 198-213.

Carlile, P.R. 2002. A Pragmatic View of Knowledge and Boundaries: Boundary Objects in New Product Development. Organization science 13 (4): 442-455.

Carlile, P.R. 2004. Transferring, Translating, and Transforming: An Integrative Framework for Managing Knowledge across Boundaries. Organization science 15 (5): 555-568.

Cassiman, B. and Veugelers, R. 2006. In Search of Complementarity in Innovation Strategy: Internal R\&D and External Knowledge Acquisition. Management science 52 (1): 68-82.

Chesbrough, H. 2003. Open Innovation: The New Imperative for Creating and Profiting from Technology. Boston, MA:Harvard Business School Press.

Chesbrough, H. 2006. Open Business Models: How to Thrive in the New Innovation Landscape. Boston:Harvard Business School Press. 
Chesbrough, H. and Bogers, M. 2014. Explicating Open Innovation: Clarifying an Emerging Paradigm for Understanding Innovation. New Frontiers in Open Innovation. Oxford: Oxford University Press, Forthcoming.

Cohen, W.M. and Levinthal, D.A. 1990. Absorptive Capacity: A New Perspective on Learning and Innovation. Administrative Science Quarterly 35 (1): 128-152.

Contu, A. and Willmott, H. 2003. Re-Embedding Situatedness: The Importance of Power Relations in Learning Theory. Organization science 14 (3): 283-296.

Dahlander, L., Frederiksen, L. and Rullani, F. 2008. Online Communities and Open Innovation. Industry and innovation 15 (2): 115-123.

Dahlander, L. and Magnusson, M.G. 2005. Relationships between Open Source Software Companies and Communities: Observations from Nordic Firms. Research policy 34 (4): 481-493.

Dahlander, L., \& Frederiksen, L. (2012). The core and cosmopolitans: A relational view of innovation in user communities. Organization science,23(4): 988-1007.

Dittrich, K. and Duysters, G. 2007. Networking as a Means to Strategy Change: The Case of Open Innovation in Mobile Telephony. Journal of product innovation management 24 (6): 510-521.

Dodgson, M., Gann, D. and Salter, A. 2006. The Role of Technology in the Shift Towards Open Innovation: The Case of Procter \& Gamble. $R \& D$ Management 36 (3): 333-346.

Duguid, P. 2005. "The Art of Knowing": Social and Tacit Dimensions of Knowledge and the Limits of the Community of Practice. The information society 21 (2): 109-118.

Dyer, J.H. and Singh, H. 1998. The Relational View: Cooperative Strategy and Sources of Interorganizational Competitive Advantage. Academy of management review 23 (4): 660679.

Enkel, E., Gassmann, O. and Chesbrough, H. 2009. Open R\&D and Open Innovation: Exploring the Phenomenon. R\&d Management 39 (4): 311-316.

Faraj, S., Jarvenpaa, S.L. and Majchrzak, A. 2011. Knowledge Collaboration in Online Communities. Organization science 22 (5): 1224-1239.

Feldman, M.S. and Orlikowski, W.J. 2011. Theorizing Practice and Practicing Theory. Organization Science 22 (5): 1240-1253.

Fox, S. 2000. Communities of Practice, Foucault and Actor-Network Therory. Journal of management studies 37 (6): 853-868.

Franke, N. and Shah, S. 2003. How Communities Support Innovative Activities: An Exploration of Assistance and Sharing among End-Users. Research policy 32 (1): 157-178.

Füller, J., Matzler, K. and Hoppe, M. 2008. Brand Community Members as a Source of Innovation. Journal of Product Innovation Management 25 (6): 608-619.

Gassmann, O. and Enkel, E. 2004. 'Towards a Theory of Open Innovation: Three Core Process Archetypes', R\&D management conference, vol. 6, pp. 1-18.

Gherardi, S. 2008. Situated Knowledge and Situated Action: What Do Practice Based Studies Promise? London:Sage Publications.

Gherardi, S. 2009. Community of Practice or Practices of a Community. The Sage handbook of management learning, education, and development 514-530.

Gherardi, S. and Nicolini, D. 2000. The Organizational Learning of Safety in Communities of Practice. Journal of Management Inquiry 9 (1): 7-18.

Giddens, A. 1979. Central Problems in Social Theory: Action, Structure, and Contradiction in Social Analysis. vol. 241. Univ of California Press. 
Grant, R.M. 1996. Toward a Knowledge-Based Theory of the Firm. Strategic management journal 17 (S2): 109-122.

Handley, K., Sturdy, A., Fincham, R. and Clark, T. 2006. Within and Beyond Communities of Practice: Making Sense of Learning through Participation, Identity and Practice*. Journal of management studies 43 (3): 641-653.

Henri, F. and Pudelko, B. 2003. Understanding and Analysing Activity and Learning in Virtual Communities. Journal of Computer Assisted Learning 19 (4): 474-487.

Hienerth, C., Keinz, P. and Lettl, C. 2011. Exploring the Nature and Implementation Process of User-Centric Business Models. Long Range Planning 44 (5): 344-374.

Hienerth, C., Lettl, C. and Keinz, P. 2014. Synergies among Producer Firms, Lead Users, and User Communities: The Case of the Lego Producer-User Ecosystem. Journal of Product Innovation Management 31 (4): 848-866.

Hong, J.F. and Fiona, K. 2009. Conflicting Identities and Power between Communities of Practice: The Case of It Outsourcing. Management Learning 40 (3): 311-326.

Huggins, R. 2010. Forms of Network Resource: Knowledge Access and the Role of Inter-Firm Networks. International Journal of Management Reviews 12 (3): 335-352.

Hung, D. and Nichani, M. 2002. Differentiating between Communities of Practice (Cops) and Quasi-Communities: Can Cops Exist Online? International Journal on E-Learning 1 (3): 23-29.

Jarvenpaa, S.L. and Lang, K.R. 2011. Boundary Management in Online Communities: Case Studies of the Nine Inch Nails and Ccmixter Music Remix Sites. Long Range Planning 44 (5): 440-457.

Jeppesen, L.B. and Frederiksen, L. 2006. Why Do Users Contribute to Firm-Hosted User Communities? The Case of Computer-Controlled Music Instruments. Organization science 17 (1): 45-63.

Kogut, B. and Zander, U. 1992. Knowledge of the Firm, Combinative Capabilities, and the Replication of Technology. Organization science 3 (3): 383-397.

Kogut, B. and Zander, U. 1996. What Firms Do? Coordination, Identity, and Learning. Organization science 75 (5): 502-518.

Lakhani, K.R. and Von Hippel, E. 2003. How Open Source Software Works:"Free” User-to-User Assistance. Research policy 32 (6): 923-943.

Lauritzen, G.D., Salomo, S. and La Cour, A. 2013. Dynamic Boundaries of User Communities: Exploiting Synergies Rather Than Managing Dilemmas. International Journal of Technology Management 63 (3-4): 148-168.

Lave, J. 1988. Cognition in Practice: Mind, Mathematics and Culture in Everyday Life. Cambridge University Press.

Lave, J. and Wenger, E. 1991. Situated Learning: Legitimate Peripheral Participation. Cambridge university press.

Lee, G. K., \& Cole, R. E. (2003). From a firm-based to a community-based model of knowledge creation: The case of the Linux kernel development.Organization science, 14(6): 633649.

Leonard-Barton, D. 1992. Management of Technology and Moose on Tables. Organization Science 3 (4): 556-558.

Lichtenthaler, U. and Lichtenthaler, E. 2009. A Capability-Based Framework for Open Innovation: Complementing Absorptive Capacity. Journal of Management Studies 46 (8): $1315-1338$. 
March, J. 1991. Exploration and Exploitation in Organizational Learning. Organization Science 2 (1): 71-87.

Nambisan, S. and Baron, R.A. 2009. Virtual Customer Environments: Testing a Model of Voluntary Participation in Value Co-Creation Activities. Journal of product innovation management 26 (4): 388-406.

Nicolini, D. 2011. Practice as the Site of Knowing: Insights from the Field of Telemedicine. Organization Science 22 (3): 602-620.

Nonaka, I. and Takeuchi, H. 1995. The Knowledge-Creating Company: How Japanese Companies Create the Dynamics of Innovation. Oxford university press.

O’Mahony, S. and Lakhani, K.R. 2011. Organizations in the Shadow of Communities. Research in the Sociology of Organizations 33 3-36.

Ordanini, A. and Maglio, P.P. 2009. Market Orientation, Internal Process, and External Network: A Qualitative Comparative Analysis of Key Decisional Alternatives in the New Service Development. Decision Sciences 40 (3): 601-625.

Orlikowski, W.J. 2002. Knowing in Practice: Enacting a Collective Capability in Distributed Organizing. Organization science 13 (3): 249-273.

Orlikowski, W.J. 2010. Practice in Research: Phenomenon, Perspective and Philosophy. Cambridge handbook of strategy as practice 23-33.

Piller, F. and West, J. 2014. Firms, Users, and Innovation: An Interactive Model of Coupled Open Innovation. New Frontiers in Open Innovation. Oxford University Press, Oxford.

Randhawa, K., Wilden, R. and Hohberger, J. 2016. A Bibliometric Review of Open Innovation: Setting a Research Agenda. Journal of Product Innovation Management.

Ren, Y., Kraut, R. and Kiesler, S. 2007. Applying Common Identity and Bond Theory to Design of Online Communities. Organization studies 28 (3): 377-408.

Rivette, K.G. and Kline, D. 2000. Rembrandts in the Attic: Unlocking the Hidden Value of Patents. Boston:Harvard Business School Press.

Roberts, J. 2006. Limits to Communities of Practice. Journal of management studies 43 (3): 623639.

Sapsed, J. and Salter, A. 2004. Postcards from the Edge: Local Communities, Global Programs and Boundary Objects. Organization studies 25 (9): 1515-1534.

Schatzki, T.R. 1996. Social Practices: A Wittgensteinian Approach to Human Activity and the Social. Cambridge Univ Press.

Schatzki, T.R. 2005. Peripheral Vision the Sites of Organizations. Organization studies 26 (3): 465-484.

Shah, S.K. 2006. Motivation, Governance, and the Viability of Hybrid Forms in Open Source Software Development. Management Science 52 (7): 1000-1014.

Siedlok, F., Hibbert, P. and Sillince, J. 2015. From Practice to Collaborative Community in Interdisciplinary Research Contexts. Research Policy 44 (1): 96-107.

Star, S.L. and Griesemer, J.R. 1989. Institutional Ecology,Translations' and Boundary Objects: Amateurs and Professionals in Berkeley's Museum of Vertebrate Zoology, 1907-39. Social studies of science 19 (3): 387-420.

Swan, J., Bresnen, M., Newell, S. and Robertson, M. 2007. The Object of Knowledge: The Role of Objects in Biomedical Innovation. Human Relations 60 (12): 1809-1837.

Swan, J., Scarbrough, H. and Robertson, M. 2002. The Construction of Communities of Practice'in the Management of Innovation. Management learning 33 (4): 477-496. 
Thompson, M. 2005. Structural and Epistemic Parameters in Communities of Practice. Organization Science 16 (2): 151-164.

Vanhaverbeke, W., Chesbrough, H. and West, J. 2014. Surfing the New Wave of Open Innovation Research. New Frontiers in Open Innovation 281.

Vanhaverbeke, W. and Cloodt, M. 2006. Open Innovation in Value Networks. Open innovation: Researching a new paradigm 258-281.

Vanhaverbeke, W., Van de Vrande, V. and Chesbrough, H. 2008. Understanding the Advantages of Open Innovation Practices in Corporate Venturing in Terms of Real Options. Creativity and Innovation Management 17 (4): 251-258.

Von Hippel, E. 2005. Democratizing Innovation. MIT press.

von Hippel, E. and von Krogh, G. 2003. Open Source Software and the Private-Collective Innovation Model: Issues for Organization Science. Organization Science 14 (2): 209223.

Wenger, E. 1998. Communities of Practice: Learning, Meaning, and Identity. Cambridge university press.

West, J. and Bogers, M. 2014. Leveraging External Sources of Innovation: A Review of Research on Open Innovation. Journal of Product Innovation Management 31 (4): 814831.

West, J. and Gallagher, S. 2006. Challenges of Open Innovation: The Paradox of Firm Investment in Open-Source Software. $R$ and D Management 36 (3): 319-331.

West, J. and Lakhani, K.R. 2008. Getting Clear About Communities in Open Innovation. Industry and Innovation 15 (2): 223-231.

West, J. and O'mahony, S. 2008. The Role of Participation Architecture in Growing Sponsored Open Source Communities. Industry and Innovation 15 (2): 145-168.

West, J., Salter, A., Vanhaverbeke, W. and Chesbrough, H. 2014. Open Innovation: The Next Decade. Research Policy 43 (5): 805-811.

Wiertz, C. and de Ruyter, K. 2007. Beyond the Call of Duty: Why Customers Contribute to Firm-Hosted Commercial Online Communities. Organization studies 28 (3): 347-376. 